\title{
The CounterText Interview: Simon Critchley
}

\section{Simon Critchley and James Corby}

At the end of November 2009, Simon Critchley had been due to fly out to Malta to deliver a keynote address at the 'Style in Theory / Styling Theory' Conference. ${ }^{1}$ In the event, Critchley was unable to travel. Not that the conference was short of keynote speakers - besides Critchley, there was Catherine Belsey, Douglas Burnham, Stefan Herbrechter, Fiona Hughes, Laurent Milesi, Jean-Michel Rabaté, and Stuart Sillars. Critchley’s work, however, had seemed particularly relevant to the concerns of the conference. His experiments with style had always appeared pointedly directed towards bringing out the literary in the philosophical and the philosophical in the literary. So, to ensure that Critchley would still be part of the conversation about style and theory despite him not being physically present at the conference, the next best thing was arranged - a live videolink interview.

The text presented here is an edited version of that interview and the question-and-answer session that followed, all of which took place on Friday 27 November 2009. ${ }^{2}$ The interview carries a fascinating historical situatedness, and it frames a particular moment in Critchley's intellectual development and in the evolution of 'theory' more broadly. It also offers far-reaching and insightful reflections on style in philosophy and literature that render it strikingly relevant to the concerns of CounterText.

JC: Simon, I was going to start by saying thanks for being here, but you're not here. So thanks for being there - but that doesn't sound quite right either, because in a way you are here. So, as we begin this interview I'm wondering about what this space is. Perhaps one thing we can say is that it is a virtual space that didn't exist when you started your academic career. Whatever it is, it now increasingly demands recognition as a legitimate and institutionally-colonised academic site, 
perhaps futural in its anticipation of the changing styles of academia and scholarly dissemination. This is something you seem to have embraced: one just has to glance at your Wikipedia page which, not insignificantly, is detailed - to see lots of links to podcasts and so on. And I wonder whether that is something you embrace just because it's an inevitability or whether you see it as an important opportunity?

SC: It's an important opportunity. I'm a bit of a Luddite when it comes to technology but I've got a very good assistant who does all that stuff for me. And I like free stuff, free things that you can distribute horizontally. I like the horizontal forms of communication and dissemination you get with the new media. I'm not a technology enthusiast or a technology evangelist but I'm very curious about the new forms of media, and about the pseudo-authenticity of this - that, I'm there, and I'm not there - but also the new forms of identity complication that it can produce. And fraud ... I'm very interested in fraud and theft. For example, there's a false Twitter feed for me, so messages go out from me, which aren't from me - which I quite like as a way of complicating ideas about identity. Recently I was doing some work with the International Necronautical Society, which is one of those odd projects I've been involved with for years. We did an event at the Tate Britain in January where we - my friend the novelist Tom McCarthy and I - gave a declaration on inauthenticity, except that 'we' were played by actors. ${ }^{3}$ We trained them, which took an awfully long time, they performed, and, of course, they were better at being us than we were. For a lot of people in the audience who didn't know who we were, the actors were more real than 'us'. And it goes back to that Warhol idea: before he was shot [in 1968, by radical feminist writer Valerie Solanas] he used to think that TV was reality, and after he was shot he was certain that TV was reality. So I'm interested in the new forms of impersonation, complication, and fraud that the new media allow - the ways in which the idea of authenticity, which is something I'm against, is challenged.

JC: Do you follow that Twitter feed? 
SC: Not really, no ... strangely enough.

JC: There's a fake Žižek one as well.

SC: Yes, and there's been a fake debate between the fake Žižek one and my fake one which is sort of interesting.

JC: Turning to style itself: it's clear from your work that style does matter. It's something that you cultivate in your own work and it's something that you are attentive to in other writers. I'd like to give you a few examples where you refer to the style of other writers. In Very Little ... Almost Nothing you remark on Emerson's style which has 'a staccato muscularity' (2004 [1997]: 145); in On Humour you speak of 'the telegraphic conciseness of [Freud's] late style' (2002: 94); in Ethics, Politics and Subjectivity you refer to Genet's style as 'simple, direct and without pretension' (1999: 35), and elsewhere in that book you claim that what one might now call Derrida's late style marks a move away from the 'theoretical' and the 'performative' towards the 'quasi-phenomenological' (97). In The Ethics of Deconstruction you refer explicitly to 'the style of deconstruction' (2014 [1992]: 14) and Levinas's 'extraordinary style of writing' (284). But I'd like to ask you about four styles in particular: the styles of Montaigne, Blanchot, Heidegger, and Beckett. In your recent Book of Dead Philosophers you refer to the 'highly personal style of Montaigne' (2008: 113), which is able 'to map the movement of the mind' (114). For Montaigne, you write, 'the manner of writing is as important as the matter' (113). You have praised Blanchot's 'limpid clarity, economy and strangeness' (2006); and you have criticised Heidegger and 'the inelegant prose of Sein und Zeit' (2004 [1997]: 227), and spoken warily of its 'dangerous power' (2006). Beckett is clearly a very important writer for you, and there is a tantalising footnote in Very Little ... Almost Nothing, which you don't really develop, in which you defend Beckett against J. M. Coetzee's suggestion that Beckett's style is a prison (2004 [1997]: 264, n.71). I wonder if you could elaborate on the styles of these four writers? 
SC: It's a brilliant question. Style is a hugely important issue for me. Let me take those four writers in turn. What interests me about Montaigne is - well, all sorts of things - but what interests me in particular is what I like to think of as informal philosophy, as opposed to the formal, impersonal style of, say, analytic philosophy. What you get in Montaigne is an informality, an informality that seems to map the movements of the mind. Montaigne's writing is also autobiographical - it's autobiographical and extraordinarily intimate, but it's not selfobsessed. In fact, Pascal said about Montaigne somewhere that it's not Montaigne we see when we read Montaigne, it's us. And also there's the way in which he uses citation, which is something I'm interested in in other contexts - that there's a style of building, as it were, an informal accumulation of citation, which for me is a precursor to that Benjaminian idea of citation without citation marks. In Montaigne you get that massive accumulation of citation.

In relation to Blanchot: the first book I ever read in French was L'Espace littéraire. It was so limpid and wonderful to read. I've always been fascinated and perplexed by Blanchot's style the mini-essays he did for Nouvelle Revue Française were so incredibly clear and limpid, and yet at the same time you have this obscurity. What Blanchot was able to do was to write short, clear essays that at the same time give you this sense of a huge opaque terrain, a numinous terrain at the back of his discourse. I've never been able to mimic it and very few people can.

Heidegger remains, for me, the philosopher, for good or ill ... for good and ill, rather. It seems to me that Heidegger's career is a career in style. I've been doing work on the early Heidegger for a number of years but it seems to me that all that changes in Heidegger's work is the style. We have the same matter, the same matter of thinking, but with different approaches to that matter. He goes from the lecture, the philosophical treatise, through to autobiographical rumination in Beiträge, through to rather bad poetry, to the essay, to different forms of meditation, to whatever .... So, in a sense, Heidegger is all about style, and maybe the tragedy of Heidegger's work is that what he does is to continue to try to build castles of style in the air in an attempt to, as it were, capture this matter. 
Beckett, for me, is the man. What fascinates me about Beckett is the neutrality of his style, and also the fact that this is a style that is mediated through a foreign language. Beckett only becomes Beckett through the mediation of French, so you have a style of writing in a second language and the necessary impoverishment of one's language that that enforces. And then there's the humour in Beckett, which, for me, is exemplary - ' There is rapture, or there should be, in the motion crutches give' (2009 [1947]: 59), and so on. But also there is something in that stripped-down style - what Barthes used to call 'degree-zero' style - that is also capable of expressing extraordinary pathos. So what I particularly like in Beckett are the late short prose pieces like IIl Seen Ill Said (1982) and Company (1980), which, in this extraordinary, almost neutral, impersonal style, evoke an incredibly powerful affect. There's nothing affectless about Beckett on the contrary.... As Badiou (2003) said, there's even a nostalgia in Beckett, and I find that nostalgia very compelling. So these four authors have been exemplary in different ways for me.

JC: I wonder if we could move on to the development of style in your own work, and its implications. The first book you published was The Ethics of Deconstruction. Now, first books often have their own style, but what interests me is why, after the publication of this book, you were, in your own words, 'determined to make the second book as different as possible' (2006)? More specifically, I wonder whether it has to do with what seems to be your equivocal relationship with 'theory'? In the 'Preface' to the second edition of your second book, Very Little ... Almost Nothing, you declare that structuralism is a term you have 'never really understood', poststructuralism is a 'term you neither use nor recognize', and that postmodernism is a term which you are 'on record in numerous places as disapproving [of] for both philosophical and sociological reasons' (2004: xxvii). Elsewhere in Very Little ... Almost Nothing you refer to the 'rather precious and irritating prose style' of Lacoue-Labarthe and Nancy's The Literary Absolute (136). And yet The Ethics of Deconstruction emerged from, and arguably is characterised by, some aspects of the style of that heady theoretical milieu. My question is: how, if at all, did an uneasy relationship with theory shape your second book, Very Little ... Almost Nothing?

SC: OK, a little bit of context here: Catherine Belsey ${ }^{4}$ put me in touch with a very good editor at Blackwell called Stephan Chambers. I don't know what happened to Stephan, but he was a great 
editor, and way back in 1990, or whenever, he took a risk on The Ethics of Deconstruction. It happened to be published a month after the Cambridge affair, when Derrida was initially denied an honorary doctorate at Cambridge. There were the headlines like 'Value-Free Nihilism Hits English City', and deconstruction was suddenly front-page news. What was at the centre of that was the question of nihilism and the question of whether this was a value-free approach ... and then The Ethics of Deconstruction came out and benefited from that. But its success was also thanks to a clever editor - I wish there were more of them out there.

After managing to get a book published and read, there can be a danger of then writing the same text over and over again. I was determined not to do that; I was determined to write something as far away as possible from The Ethics of Deconstruction, and that became Very Little ... Almost Nothing. So it was a desire to do something different. But there is also, running through that book, an anxiety about theory. I've always been very suspicious of a 'supermarket' approach to theory - the idea that you take an object, whatever it might be, Middlemarch for instance, and you then read it in a Marxist or a Feminist or a poststructuralist way. That seems to me to betray the object. What I try to do in relation to whatever I'm thinking about is to follow the particular, to trace the material particular artwork, literary work, whatever it might be, and to try to find some affluence of that thing in one's writing. And that comes back to style. So, I've always been anxious about a 'supermarket' approach to theory and the temptation to reduce it to a series of terms like poststructuralism, postmodernism, and the rest. I learnt how to talk the talk of structuralism but I just never felt it. That's mainly my problem.

JC: For the second edition of Very Little ... Almost Nothing you rewrote parts of it in, as I understand it, an explicit effort to try to 'improve the style' (2004: xxviii). Looking back on the re-working of your second book, how do you feel about it now? How do you view it? I suppose the underlying question is, does style change with age?

SC: Yeah, a lot of things change with age. I've got a relationship of what Lacan would call 'hainamoration' (Lacan 1998: 90), love / hate, for Very Little ... Almost Nothing. I understand what it is people say they like in the book, but I don't really see it myself. I find it over-written 
and painful to read. It's about my father, but it's not really about my father. There's nothing obvious about that in the text, but for me it's about him and I still miss him. Terribly. Age in a way clarifies style, one can say. You get to a point where you can say things more clearly than you could when you were younger. But having said that, I've been writing some of my most obscure stuff recently and I've really been messing with style in a whole range of different ways. I was writing something recently on David Lynch's Inland Empire (2006) with my wife that's extremely obscure (Critchley and Webster 2009), and something on 'Mystical Anarchism' that's maybe even more obscure (Critchley 2009a). Style in relation to collaboration interests me very much - how extended forms of authorship affect questions of style. There is one writing oneself, but what I'm trying to do in a whole number of different ways is to work with other people, to write with other people, and that does something very interesting to your style. When you write with somebody you admire and trust, your prohibiting, inhibiting superego shuts down a little bit and you find yourself saying things that you wouldn't normally say, and that can be really exciting.

For example, I worked with the novelist Tom McCarthy - who is a genius. What's interesting about that collaboration in relation to style is that, as an academic or as a philosopher, there's perhaps a tendency to think in lines, lines of argument, or vertically, in terms of assembling a series of conceptual distinctions or whatever, whereas he thinks horizontally and 'associationally'. So he'll say: there's this moment here in Shakespeare, which is like this moment in Faulkner, which is like this moment in Nabokov, which reminds me of this episode of Scooby-Doo, or whatever it might be ... so there's this accumulation of associations. I'm very interested in people who work horizontally and people who work vertically, and the two things together can be rather liberating.

There's been a lot of emphasis on collaboration and joint authorship in contemporary art and literature over the last fifteen, twenty years. For me it always comes back to the idea of constructing something like a collective intelligence, or the idea of a group of some sort where you can, as it were, lose yourself in forms of collaborative practice. For example, I'm very enthusiastic about a Parisian artist called Philippe Parreno, with whom I'm collaborating on some projects at the moment. And this is part of an attempt to sort of lose ourselves in each other's work - we read the same books, he works in images, I work in words. So, for me, 
collaboration is something incredibly exciting at the level of style. In the International Necronautical Society we deliberately use the style of the manifesto, in particular Marinetti's Manifesto of Futurism of 1909. We use that style in order to produce a sort of declaration, a manifesto. That interests me. And then there are other forms of style - the conversation, the polylogue. There are endless possibilities, it seems to me, which need to be explored, particularly in relation to how style can break down the unit of individual production. I'm very keen on that. What's happened in Britain - one of the reasons why people like me got out, and it's also the case elsewhere - is that the individual became the unit of production in the humanities and social sciences, and I think collaborative work is a way of undermining that. And also, as I said before, you can lose your inhibiting superego a little bit when writing and working collectively, and that can only be a good thing.

I'm also interested in blogs - blogs as style, and how they can be used. This year I've been experimenting with things for The New York Times ${ }^{5}$ and The Guardian (Critchley 2009b), using the format of the 800-word lump of text as a way of explaining something, or trying to address something. The discipline required there is interesting.

JC: And are you ever conscious of adapting your written and intellectual style to suit the thing you are writing about? I'm particularly interested in whether this might be the case when writing about art forms like poetry and film?

SC: Absolutely - completely and unreservedly. Art is about repetition and theft, and so is what we do. A hugely important essay for me has always been Blanchot's 'Literature and the Right to Death' (1981). In that essay, Blanchot talks about the two slopes of literature, the two pistes that you can ski down, as it were. One is the slope of the reduction of matter to form. On this slope, things become matter that can be formalised - rendered, or aufgehoben in the Hegelian sense into the form of conceptuality. Blanchot associates this approach with the work of Hegel and with the pornography of the Marquis de Sade. That's one slope. The second slope is the attempt to let matter matter, as it were, to not reduce matter to form, but to let matter be matter. Those are the last words, actually, of Flaubert's The Temptation of Saint Anthony (2001 [1874]), which 
is a text that interests me for all sorts of reasons. Blanchot is thinking about a number of things there, but one poet that's on his mind is Francis Ponge. If you think about Ponge's poem on the orange, what he's attempting to do there is to let the orange orange. For me, style is about trying to follow the particular, trying to follow the object. This comes back to what I'm suspicious of in 'theory', which is the reduction of particulars to some framework, some grid which makes them intelligible. I want to do exactly the opposite and show how theory - theoretical discourse, conceptual discourse - meets a certain limit when it confronts an object. The way I tried to describe this recently is as a difference between two different approaches. One is a 'philosofugal' approach, where philosophical concepts spread themselves over objects - think of Lacanian film theory, where every film suddenly looks the same. We go searching for the break-down of the symbolic and find the moment of the real in every movie. There's a danger there. The other approach, and it is the one that I try to follow, is a sort of 'thingopetal' approach to style, where, in a sense, the writing tries to find some adumbration, some affluence of the material thing. You try to borrow from the object as closely as possible.

JC: An abiding concern of your work is human finitude and the question of how one should live - or perhaps one could say, how one should style one's being - in relation to death. It seems to me that in many ways this might take us to the heart of your own style - understood in the widest possible sense - which I would venture to describe as an ataraxic style. Ataraxia refers to a calmness born of an acceptance of our finitude in a godless universe. As an intellectual style this ataraxia seems to determine the sort of poetry that interests you (Pessoa, Stevens), the sort of humour that most appeals to you (the Beckettian risus purus), and the sort of philosophers that fascinate you most. But I would go further and suggest that in your work you have developed a distinctly 'ataraxic' aesthetic style too, one that conjures a certain poise and a sense of detached calm - calm being a word that seems to be important in your lexicon - that can at times be both compelling and strangely disconcerting. It's said we never really know our own style, but I wonder whether there is anything in this description of ataraxic style that you recognise as your own? 
SC: Yeah ... again I begin from Blanchot's idea that our relationship to our own work is one of self-deception, which is an idea that Paul de Man develops in Blindness and Insight - you know, that one is blind to what one does. So, I am blind to what I do. I hope you're right - but I couldn't possibly say. You were always such a good and careful reader, James, and I have no rights or authority over these things. But I can say something in relation to calm and ataraxia. Calm crept into my discourse when I was writing an essay on Terrence Malick, and, just at the level of association, I made a link to the moment in Heidegger's 'What is Metaphysics?' when he talks about anxiety, angst as a form of Ruhe, as a form of calm or peace (Heidegger 1998 [1929]: 88), and it was that calm or peace that the protagonist in Malick's Thin Red Line (1998) was trying to achieve in relationship to death. So it crept into my vocabulary there. I also found it all over Wallace Stevens's late poetry and I was very interested by that. Again, this goes back to the question of style and age. If you look at Stevens's style, he goes from a florid, manneristic gaudiness in the early poems, assembled in Harmonium, to this incredibly spare style in the late works - 'The Plain Sense of Things', 'Not Ideas About the Thing but the Thing Itself' - which attempt to, as it were, follow things - material, natural things - with a certain calm. So I'm interested in that disposition of calm ... and then it's just a step back to Epicurus, and Epicurus' use of ataraxia in the letters, which interest me enormously, and also other appearances of the idea of calm in classical Greek philosophy - it's all over the place in classical Greek philosophy. I'm interested in Epicurus because of what he called the tetrapharmakos or the 'four-part cure': don't fear god, don't fear death; what is good is easy to get, and what is terrible is easy to endure. And that also relates to the idea of what it might mean to live like a god, which is something that you find in Epicurus, in some strange remarks in Plato, and later in the work of Spinoza. Spinoza's idea of blessedness or beatitude is about becoming god-like. For me, the idea of calm is tied up with that set of associations, which I'm trying to think my way through. The last thing I finished writing was something on St Paul, for an event that has just taken place in St Paul's Cathedral. ${ }^{6}$ There, in the writings of Paul, it's a question of anguish. What interests me about Paul is the style of the epistle, the epistle as an urgent communiqué to an audience, which is defined by the anguish of waiting. That's another sort of mood. So there are these different affects that float around. But what worries me about calm is the quasi-Buddhistic aspects of it. I did a piece for The New York Times in the summer that looks at a moment of calm in the second reverie of Rousseau's Reveries of the Solitary Walker (2009c). It wasn't just about Rousseau - I 
used that as a sort of ploy. Several hours after colliding with a dog in the streets of Paris, Rousseau regains consciousness. Blood is streaming out of his mouth. He looks up at the night sky, and feels calm for the first time, what he calls the 'sentiment of existence'. So I wrote about that, and then you get 400 online comments, some of which say, ${ }^{\circ} \mathrm{Oh}$, well this is just like neuroscience, right?' or other responses go, 'Oh, this is just Buddhism'. And I say: 'No! It's not Buddhism!' But I'm a little bit worried about the idea of calm now, to be honest.

JC: Yes, this is a key issue: how one translates this interest in ataraxic calm to politics. Where would political motivation come from? Your interest in politics is wide-ranging and persistent. You've mentioned St Paul, and you've written and spoken about everything from neo-anarchism to Barack Obama, and in all cases the issue of political style seems particularly important.

SC: Yeah ... Barack Obama as neo-anarchist [laughs].... I lived through the presidential election last year, which is very interesting for all sorts of reasons, but I'm not a liberal. I see Obama as the best last gasp of classical liberalism. What I wanted to do was just to read everything by him. Because the extraordinary thing about Obama that people don't seem to take seriously is the fact that this was a presidential candidacy campaign that was based on a style of autobiography. He's written two autobiographies, The Audacity of Hope, about the mother, and Dreams from My Father, about the father. I mean, Rousseau wrote three, and Rousseau was about as weird and paranoid an individual as you can imagine. Remember that David Hume says, in his ten-page essay 'My Own Life', 'It is difficult for a man to speak long of himself without vanity; therefore, I shall be short' (2007 [1776]: 215). Obama, I think, is fascinating from this question of style, because he constructs an identity, namely, the identity of Barack Obama, and I think he does so to try to cover over an extraordinary horror of the void. There's a horror of emptiness and lack of connection in Obama that writing tries to fill. And when writing doesn't fill it, there's his commitment to historically black Christianity, and then his commitment to the constitutional order of the United States. So there is something, for me, absolutely and essentially disconnected about Obama. The fact that the identity of the President of the United States is a consequence of literary style is something that I think we should attend to more. 
Neo-anarchism ... I could talk about that all day. ... A couple of things: firstly, the idea of comedy in relationship to politics is something that interests me. Let me put it this way: the first political emotion, I think, is anger. How that anger is articulated, how it finds articulation politically, is a key question. And I wish people were more angry than they are. Maybe they are more angry than they're letting on, but I wish people were more angry, because this year has seen the most extraordinary unmasking of the ideology of neoliberalism, the theology of neoliberalism that we were indoctrinated with for decades. I would hope that there was more anger. I've never really been a Marxist. I'm interested in Marx, but I was never really clever enough to be a Marxist. Over the last five or six years I've found myself drawn more and more towards forms of anarchist politics - from the anarchist tradition, Bakunin, Kropotkin, right the way through to contemporary neo-anarchist thought - and that anarchist practice of direct democracy, the construction of affinity groups, the working through of consensus, and so on, is, I think, a fascinating way in which politics can happen ... particularly under the radar in a place like the United States. There are these strong local anarchist traditions that, I think, are misperceived elsewhere, and I find this the last best hope for forms of social transformation.

\section{Questions from the Floor}

Jean-Michel Rabaté: I have a simple question relating to Levinas and the names you mentioned in passing. On my way to Malta, I stopped in Paris and I took a good look at the recently published volume of Levinas's notebooks, and what struck me was the literary nature of the style, and the ambition to be a novelist. My fairly basic (but, for me, worrying) question is whether, beyond the individual styles of, say, Levinas and Derrida, there would be something like a phenomenological style, which would be partly literary, partly philosophical, based on the accuracy of description? And, if so, would that be something you recognise as being a component of your style?

SC: Well, I'd like to think so. I'd be hesitant about comparing myself with such an eminence as Levinas. Levinas is maybe the thinker that I've been most attached to over the years, and I'm very distressed about how Levinas is read and understood. He's reduced to an idea of ethics as 
'first philosophy', Levinas's relationship to the Other, blah blah blah, and now we're meant to be moving beyond that, back to the 'Same', as in Badiou's critique of that in Ethics (2001) and so on. I find all that really fatuous because, Levinas, for me, is about style. His work - early work like De l'évasion (1998 [1935]), which is all about literature, and late work like Autrement qu'être (2004 [1974]) - are marked by an extraordinarily intense style, and a very peculiar use of syntax, and a language which he says is almost barbarous. He's also writing as a foreigner. Levinas's domestic language was Russian until the end of his life. He spoke Yiddish, Russian ... And he never had a professorship in philosophy because he didn't do the agrégation. He didn't do the agrégation because his French accent was too poor - he was told by Léon Brunschvicg, I think - and his Latin and Greek were not adequate. There's a sort of agony of style there. It's a foreigner's inhabitation of the French language, and I find that very interesting. Levinas's key early concept of the il y a, the 'there is', is something that arises out of an experience of the literary and then, in turn, informs the experience of the literary. So, this concept is like a pingpong ball between Levinas and Blanchot, where Blanchot's early récits are a sort of elaboration of this idea of the 'there is', the sheer 'there is' of things; that's something I've always been enormously attached to. It's the idea of a reversal of intentionality. So, if phenomenology is about the intentionality thesis, what you find in Levinas is the attempt to reverse the order of intentionality, which comes to this idea of the horror of the il y a, tracking that neutral anonymity of things. So when I was talking about Ponge earlier on, what we're trying to track in those particulars is their thereness, that dark shadowy thereness that resists us. So, yeah, I still think of myself as a phenomenologist, for sure.

Gloria Lauri Lucente: James started the interview by saying that you are here with us, but not within this space. And, I have a question to you from someone who's neither within this space nor within your space, but he's in New Haven right now: Giuseppe Mazzotta. He was unable to attend, but he sent me this question to ask you, so I'm ventriloquising Giuseppe Mazzotta right now, and he quotes Deleuze, who in his book on Proust (2008 [1964]), suggests that style is a perspective or a way of seeing. Now, is style then tied to a modern principle of individuality? Mazzotta adds that this implication sounds rather absurd, for it does not explain the style of antiquity. 
SC: I don't know. I don't know whether style is something modern in that way. ... Let me give a sort of partial answer in relationship to American literature, or American thought. There is something that goes on in Emerson's essays, a hugely idiosyncratic style of thinking, like an American Montaigne. The particular accumulation of citation and aphoristic insights seems to unleash both a style that is distinct from European styles, and, as it were, an idiosyncratic idea of style that you find developed in obvious ways in Whitman, in Melville, and right the way through to more contemporary poetry. So what interests me about, say, American poetry - and this is a banality, but it's an interesting one - is that the form is very much a development of individual style. So each great American poet seems to have their own style, whether it's William Carlos Williams, or Stevens, or Ashbery, or whoever. But, more generally, I don't know ... the question of style in antiquity is very complicated. I've been doing some work on antiquity over the last few years, and, sure, there are dramatic differences of style. But really, we've got no clue - I mean, the style of the dialogues in Plato's dialogues is absolutely opaque to me - increasingly so the more time I spend reading them. Of course, you can't disentangle these things from their reception. When I read the Pre-Socratics, it's like reading surrealist poetry - but that obviously wasn't the case for the Pre-Socratics themselves.

Mark Robson: I would like to link a couple of things that have come up so far. James used the word calm about your style, but I want to talk about that as 'patience' instead, because your suggestion that your reading is a kind of response to an object and you're always trying to respond to whatever it is that you're confronted with. I wondered how that may have shifted as your work has become more explicitly political, because one of the necessities within political responses is the kind of impatience and anger, as you suggested. So would that demand a different style of reading?

SC: Yes, it's a good point. At the level of style, if you compare, say, The Ethics of Deconstruction with Infinitely Demanding, there's a very different style. I think Infinitely Demanding is an infinitely better book, but it's incredibly economical - there's a concision there 
that I wasn't capable of in my earlier work. Let's put it this way: a name that's missing from Infinitely Demanding is the name of Derrida (I think maybe it makes it into a footnote). There was a tendency amongst certain inheritances of deconstruction towards prolixity, one could say, which didn't seem to match the urgency of the times, and that left me feeling slightly frustrated. What I tried to do in Infinitely Demanding was to write in an incredibly concise theoretical style that I guess was influenced by another style, which, to give it a proper name, is the style of Badiou. I was reading Badiou's thinking quite closely from around 1994-95, but it had an effect not on what I was thinking, but rather on the way I choose to express that thought. So although there are many irritating things about Badiou's work, and many things to criticise, I find the economy of the expression incredibly powerful, and it's linked to a certain impatience, an impatience that I ended up having, say, with the style of deconstruction. Let me put it that way.

Ben Hutchinson: You mentioned St Paul and his epistles, and St Paul was shipwrecked here in Malta, of course. Combining these two things, the epistle and the shipwreck, I was thinking of the message in a bottle. Osip Mandelstam - and Celan picks up on this - uses the idea of a message in a bottle as a description of a poem. The idea is that the poem should be like a message in a bottle, thrown out but not to anyone in particular. So there would be a degree of directionality, but an intransitive directionality. I'm just wondering if that applies to style, whether one could see style in those terms - building on what you said about the idea of the epistle.

SC: Yeah, you could. What interests me in the style of Paul is the fact that here we have a hundred-odd pages of epistles that were written over a ten-year period, and they're marked by an absolute urgency and defined by a mood of anguish. And they're addressed to specific communities - Paul is addressing the Corinthians, the Galatians ... peoples he visited, with the exception of the Romans, whom he had hoped to visit on his way to Spain, the very ends of the earth in his world. And so, what interests me about Paul at the level of style is the idea of the epistle as that which is addressed punctually to a community which is in relationship to a series of other communities, and how the style of each of the epistles is different. When he's talking to 
the Corinthians he's talking about problems of ecstatic experience, glossolalia, mystery, religion, and all the rest. When he's talking to Galatians, it's to do with the issues of the relationship to Jewish Christianity, and so on and so forth. I'm very interested in that. So, in a sense, Paul's epistles are messages in bottles that manage to wash up on the shore in an extraordinarily massive way.

And there's an interesting connection here. There's been an awful lot of student protest in the last year - it's now taking place in the California system because of the cuts there, and we've had a long and bloody campaign at the New School to do with our president. But that's produced an interesting style of intervention. The texts associated with the Tarnac Nine and The Invisible Committee - Tiqqun, The Theory of Bloom (see Tiqqun 1999, 2000, 2001), and all those texts are extremely interesting at the level of style because what they've unleashed amongst the student activists that I'm in touch with is a rapid dissemination of written texts that are distributed by hand. So every week or two someone will come into my office and hand me a text and say 'Read this', and then leave. There's a deliberate avoidance of new forms of technology Facebooking, social networking - and the attempt to cultivate a network by an actual manual transmission of a text, and that text is written in an incredibly impatient style, which recalls forms of Situationist intervention from the 60s, which I find incredibly interesting. What these kids are doing - and they are kids - they're hoping, they're sending messages in bottles ... because they're a little bit angry ...

JC: Thanks Simon - thanks for being there.

SC: Thank you very much, James. 
Notes

1. The 'Style in Theory / Styling Theory' Conference was organised by Ivan Callus, James Corby, and Gloria Lauri-Lucente, and took place at the University of Malta's Valletta Campus on 26-28 November 2009. A number of papers from the conference were developed into articles and published in Style in Theory: Between Philosophy and Literature (Callus, Corby, LauriLucente 2013).

2. Special thanks to Giuliana Barbaro-Sant and Elsa Fiott for their help transcribing this interview.

3. International Necronautical Society, The Tate Declaration: Joint Statement on Inauthenticity, 17 January 2009, <http://necronauts.net/declarations/ins_inauthenticity_new_york/inauthenticity_tate.html> [accessed 26 November 2015].

4. As a keynote speaker at the Style in Theory / Styling Theory conference, Catherine Belsey was present in the audience during this interview.

5. 'The Stone' <http://opinionator.blogs.nytimes.com/category/the-stone/>

6. The event, which had taken place two days before this interview, was a conference called 'Paul Unbound: The Apostle Yesterday, Today and Tomorrow'. 
References

Badiou, Alain (2001), Ethics: An Essay on the Understanding of Evil, trans. by Peter Hallward, London and New York: Verso.

Badiou, Alain (2003), On Beckett, ed. by Nina Power and Alberto Toscano, Manchester: Clinamen.

Beckett, Samuel (1980), Company, London: Calder.

Beckett, Samuel (1982), Ill Seen Ill Said, London: Calder.

Beckett, Samuel (2009 [1947]), Molloy, in Three Novels: Molloy, Malone Dies, The Unnamable, New York: Grove Press.

Blanchot, Maurice (1981), The Gaze of Orpheus, And Other Literary Essays, trans. by Lydia Davis, New York: Station Hill Press.

Callus, Ivan, James Corby, and Gloria Lauri-Lucente (eds) (2013), Style in Theory: Between Literature and Philosophy, New York and London: Bloomsbury.

Critchley, Simon (1999), Ethics, Politics, Subjectivity: Essays on Derrida, Levinas and Contemporary French Thought, London and New York: Verso.

Critchley, Simon (2002), On Humour, London and New York: Routledge.

Critchley, Simon (2004 [1997]), Very Little ... Almost Nothing: Death, Philosophy, Literature, $2^{\text {nd }}$ edn, London and New York: Routledge.

Critchley, Simon and Mark Thwaite (2006), Interviewed for Ready Steady Book, $<$ http://www.readysteadybook.com/Article.aspx?page=simoncritchley $>$ [accessed 26 November 2015].

Critchley, Simon (2008), The Book of Dead Philosophers, New York: Random House.

Critchley, Simon (2009a), 'Mystical Anarchism', Critical Horizons: A Journal of Philosophy and Social Theory, 10: 2, 272-306.

Critchley, Simon (2009b), 'Being and Time', in The Guardian, <http://www.theguardian.com/commentisfree/belief/2009/jun/05/heidegger-philosophy> [accessed 12 December 2015].

Critchley, Simon (2009c), 'Happy Like God', in The Guardian, <http://opinionator.blogs.nytimes.com/2009/05/25/happy-like-god/> [accessed 12 December 2015] 
Critchley, Simon (2014 [1992]), The Ethics of Deconstruction: Derrida and Levinas, $3^{\text {rd }}$ edn, Edinburgh: Edinburgh University Press.

Critchley, Simon, and Webster, Jamieson (2009), 'What is the Hole Inside the Hole: On David Lynch's Inland Empire', Bedeutung, 1 <http://www.bedeutung.co.uk/magazine/issues/3life-death/critchley-webster-lynch-empire/> [accessed 12 December 2015].

Deleuze, Gilles (2008 [1964]), Proust and Signs, trans. by Richard Howard, London: Continuum.

de Man, Paul (1986 [1983]), Blindness and Insight:Essays in the Rhetoric of Contemporary Criticism, $2^{\text {nd }}$ edn, London: Routledge.

Flaubert, Gustave (2001 [1874]), The Temptation of St Anthony, trans. by Lafcadio Hearn, New York: Random House.

Heidegger, Martin (1998 [1929]), 'What is Metaphysics?', in Pathmarks, ed. and trans. by William McNeil, Cambridge: Cambridge University Press, pp. 82-96.

Hume, David (2007 [1776]), 'My Own Life', in An Enquiry Concerning Human Understanding and Other Writings, ed. by Stephen Buckle, Cambridge: Cambridge University Press.

Inland Empire (2006), dir. David Lynch, perf. Laura Dern, Jeremy Irons, Justin Theroux, France: StudioCanal.

Lacan, Jacques (1998), On Feminine Sexuality: The Limits of Love and Knowledge, 1972-1973, ed. by Jacques-Alain Miller, trans. by Bruce Fink, New York: W. W. Norton.

Levinas, Emmanuel (1998 [1935]), De l'évasion, Paris: Livre de Poche.

Levinas, Emmanuel (2004 [1974]), Autrement qu'être ou au-delà de l'essence, Paris: Livre de Poche.

Tiqqun (1999), Tiqqun, Organe conscient du Parti Imaginaire: Exercices de Métaphysique Critique, Capodarco di Fermo: Litografica Com.

Tiqqun (2000), Théorie du Bloom, Paris: La Fabrique.

Tiqqun (2001), Tiqqun, Organe de liaison au sein du Parti Imaginaire: Zone d'Opacité Offensive, Paris: Les Belles-Lettres.

The Thin Red Line (1998), dir. Terrence Malick, perf. Jim Cazaviel, Sean Penn, Nick Nolte, US: 20th Century Fox. 